\title{
Management of Water Supply Reservoirs under Uncertainties in Arid and Urbanized Environments
}

\author{
B. F. Alemaw, E. O. Keaitse, T. R. Chaoka \\ Department of Geology, University of Botswana, Gaborone, Botswana \\ Email: alemaw@mopipi.ub.bw, bfalemaw@gmail.com,chaokatr@mopipi.ub.bw
}

How to cite this paper: Alemaw, B.F., Keaitse, E.O. and Chaoka, T.R. (2016) Management of Water Supply Reservoirs under Uncertainties in Arid and Urbanized Environments. Journal of Water Resource and Protection, 8, 990-1009.

http://dx.doi.org/10.4236/jwarp.2016.811080

Received: September 9, 2016

Accepted: October 23, 2016

Published: October 26, 2016

Copyright $\odot 2016$ by authors and Scientific Research Publishing Inc. This work is licensed under the Creative Commons Attribution International License (CC BY 4.0).

http://creativecommons.org/licenses/by/4.0/

\begin{abstract}
Simulation and evaluation study of the three Water Supply Reservoirs in the Notwane Catchment was undertaken using a hybrid modelling approach linking the reservoir simulation model (HEC-ResSim) model and a reservoir reliability analysis (RRA) model. It was used to understand the management challenges and operation aspects facing the recent failure and declining water supply from three reservoirs in Gaborone and the surrounding areas, a typical arid and urbanized environment where current and future water supply reliability is challenged by both climate and anthropologic factors. The model was analysed for a calibration period of ten years (1993-2002), and verification period of eight years (2003-2010) and then simulation period of 40 years (2011-2050). The simulation period up to the year 2050 was considered to include the year 2035, which is the planning horizon of the National Water Master Plan. The model calibration and verification results are satisfactorily accepted for the fit of the daily water levels. The values of $\mathrm{R}^{2}$ and the Nash-Sutcliffe model efficiency criteria for the calibration period, are $0.81 / 60 \%, 0.62 / 27 \%$ and $0.54 / 39 \%$ for the Bokaa dam, Gaborone dam and Nnywane dam, respectively. Various scenarios were considered to determine the plausible sources of uncertainty and challenge for operation and management of the water supply reservoirs considering: population and urbanization, sedimentation, seepage, climate change, operational aspects, among others. From the RRA model, it was found that Gaborone dam, which is the largest of the three dams has lower resilience, lower reliability and higher vulnerability associated with increasing population pressures, urbanisation and climatic factors. Climate change, sedimentation, seepage, operational rules, contributing to the operation and management of the dams could have accelerated the drying up of the reservoirs and the prevailing water supply situation, which might continue to be the future possible challenges of water supply in the area.
\end{abstract}




\section{Keywords}

Operation, Reservoirs, Management, Resilience, Reliability, Vulnerability, Sedimentation, Seepage, Climate Change, Population, Urbanization

\section{Introduction}

Surface water resources are the main source of water supply for urban areas in Botswana. Around 34 percent of the total water supply is from surface water, whereas the remainder (66 percent) is from groundwater [1]. However, surface water accounts for 90 percent of the total supply of water in urban areas such as Gaborone, Lobatse, Francistown, and Selibe-Phikwe. According to Central Statistics Office [1], water from reservoirs and rivers yields about one-third to national water consumption.

Reservoirs are one of the most valuable tools for integrated water resource development and management. However, their operation and management are still a challenge for integrated water resource development and management. With the increasing population, climate change and rapid development of the economies, the function and operation of reservoirs has become more and more important to help meet society's energy and water requirements [2].

The water supply system of the Capital city of Botswana, Gaborone and its surrounding villages which heavily depend on the reservoirs found in the Notwanecatchment is a case in point. In recent years, the dam levels reached water levels which could not cope with the water demand causing water shortages and emergency situations to offset the water crisis. This was because of possibly a combination of human, climatic and operational factors.

The aim of this study was to analyze the possible impact of various aspects of human activities on water resources in the Notwane subbasin. Most of them are directly related to the catchment itself, as e.g. significant increase in population, urbanization and water demand in recent decades, and construction of a number of storage reservoirs changing the temporal pattern of river flow. Some may be, however, a result of climate change, seepage from the dams, loss of live storage of dams due to sedimentation, and operational patterns, among others.

We have employed a hybrid modelling approach linking the calibrated reservoir simulation model (HEC-ResSim) model and a reservoir reliability analysis (RRA) model to understand the current state of affairs in the water supply situation and the future resilience of the water supply reservoirs., This research centers on contributing to the management and operation of the Gaborone, Bokaa and Nnywane dams by coming up with a fitting mechanism to augment and enhance the overall management of the reservoirs through the use of a simple simulation model (HEC-ResSim) to simulate different scenarios and its evaluation using reservoir reliability analysis (RRA) model. The later model undertakes model reliability, resilience and vulnerability analysis of the reservoirs studied. 
A wide variety of analysis techniques including simulation and optimization algorithms have been developed over the last few decades to study water resources systems [3] [4] [5]. Simulations describe the movement of water through a system while optimization programs search for an optimal operating policy to achieve a specific given objective. According to [6], in discussing large, multi-reservoir systems, the distinction between simulation and optimization modeling is often concealed and obscure because optimization models usually involve simulation models in verifying and testing proposed operating policies. Simulation modeling offers a useful platform for explicitly testing specific possibilities for intergratively operating reservoirs and is the focus of further discussion. Simulation models use inflows (hydrology), operations (decision rules), and mass balance basin accounting (connectivity) to represent the hydrologic behavior of a reservoir system.

System performance is quantified by selecting indicators based on system flow and/or storage whichever that the modeler feels best characterizes the key aspects and objectives of the system. In order to carry out simulation analysis, the performance is computed using selected indicators for a base case representing the system's existing hydrologic behavior. Next, the modeler develops a series of alternative system behaviors by changing reservoir storage allocations, operating rules, demand/abstraction levels, and/or hydrology and many others after which he/she computes performance for these hypothesized alternatives. Lastly, the modeler compares the base case performance to that of the developed alternatives. The majority of the simulation procedure involves formulating alternatives to test, evaluate, analyze and explicitly modeling them.

\section{The Study Area}

The Notwane River sub-basin/catchment is located in south eastern Botswana bounded by latitude of $23^{\circ} \mathrm{S}$ and $25^{\circ} \mathrm{S}$ and longitude $25^{\circ} \mathrm{E}$ and $27^{\circ} \mathrm{E}$ encapsulating an area of about $18,263 \mathrm{~km}^{2}$ (Figure 1). The Notwane sub catchment is part of the greater Limpopo Basin, which has Botswana, Mozambique, South Africa and Zimbabwe as the riparian states.

The catchment has many dams of which most are small farm dams for livestock watering and irrigation projects. The larger dams of Gaborone, Bokaa and Nnywane are managed by WUC for water supply purposes to the greater Gaborone area. Their characteristics are in Table 1. Greater Gaborone area comprises Gaborone, Lobatse, Mogoditshane, Tlokweng, Ramotswa and Mochudi.

\section{Method and Data}

\subsection{HEC-ResSim Simulation Software}

The US Army Corps of Engineers (USACE) has also developed numerous reservoir simulation tools including HEC-3 [8], HEC-5 [9], HEC-ResSim 2.0 [10], and most recently, HEC-ResSim 3.0 and 3.1 [11] [12]. HEC-ResSim in particular has been successfully implemented for the analysis of multiple reservoir systems throughout the US and the world [13]. It was designed by the Hydrologic Engineering Center (HEC) of the 


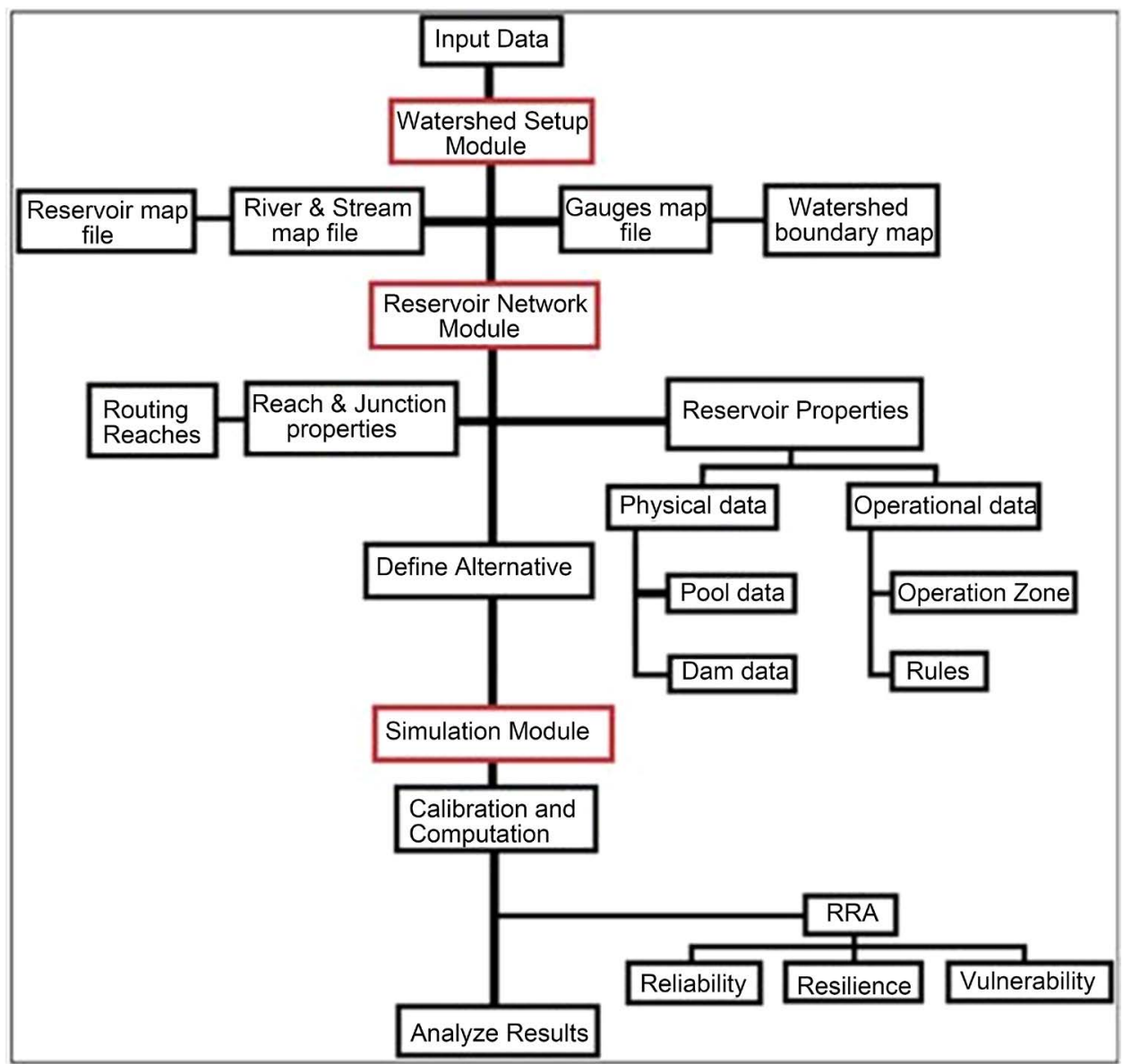

Figure 1. Summary of the hybrid HEC-ResSim and RRA model framework.

Table 1. Dams in the Notwane catchment and their parameters [7].

\begin{tabular}{|c|c|c|c|}
\hline Dam Parameters & Gaborone Dam & Bokaa Dam & Nnywane Dam \\
\hline Dam Type & Earthcore Fill & Earthcore Fill & Earthcore Fill \\
\hline River dammed & Notwane & Metsimotlhabe & Nnywane \\
\hline Year Constructed & 1963, raised 1984 & 1993 & 1970 \\
\hline Full Supply Level (FSL) & EL 998 masl & EL 954 masl & EL 1135 masl \\
\hline Spillway Length & $272 \mathrm{~m}$ & $690 \mathrm{~m}$ & $80 \mathrm{~m}$ \\
\hline Catchment Area & $4300 \mathrm{~km}^{2}$ & $3570 \mathrm{~km}^{2}$ & $238 \mathrm{~km}^{2}$ \\
\hline Active Storage & $141.5 \mathrm{MCM}$ & $18.82 \mathrm{MCM}$ & $2.3 \mathrm{MCM}$ \\
\hline Surface Area (FSL) & $19 \mathrm{~km}^{2}$ & $6.6 \mathrm{~km}^{2}$ & $1.65 \mathrm{~km}^{2}$ \\
\hline Dead storage & $3.71 \mathrm{MCM}$ & $0.25 \mathrm{MCM}$ & $0.002 \mathrm{MCM}$ \\
\hline Area supplied & Greater Gaborone & Greater Gaborone & Greater Gaborone \\
\hline $\begin{array}{c}\% \text { contribution to area } \\
\text { supplied }\end{array}$ & $56 \%$ & $25 \%$ & $10 \%$ \\
\hline
\end{tabular}


US. Army Corps of Engineers specifically for aiding in decision-making processes for reservoir operations and planning [12]. The program has been upgraded over time to allow users to have additional operational parameters and access output results in more intuitive formats. ResSim employs a GUI to allow point-and-click model construction and can function on multiple user-defined time steps.

HEC-ResSim uses a rule-based approach to govern reservoir release and hydropower generation. The model is purely descriptive, that is it does not have optimization capabilities. Res-Sim uses the HEC Data Storage System (HEC-DSS) for entry, storage and retrieval of input and output time-series data in the model. ResSim has three main modules which are the Watershed Setup, Reservoir Network and Simulation (Figure 1). Each module has a specific purpose and associated set of functions which are accessible by menus, toolbars and schematic elements.

The summary of the hybrid HEC-ResSim and RRA model framework is given in Figure 2.

The development of the reservoir network is the second most important task in building up of the model. This is where junctions, reaches and reservoirs of the watershed are established. It is made up of two major highly inter-related components, which are namely the physical and operational parts of the model (Figure 1). The physical part includes the dam and other accessory components of a dam structure like the spillways, hydropower plants, outlet groups, storage-area-elevation relationship, evaporation and seepage [12]. The operational part comprises reservoir release rules and reservoir storage zones. The operational data symbolizes the goals and constraints

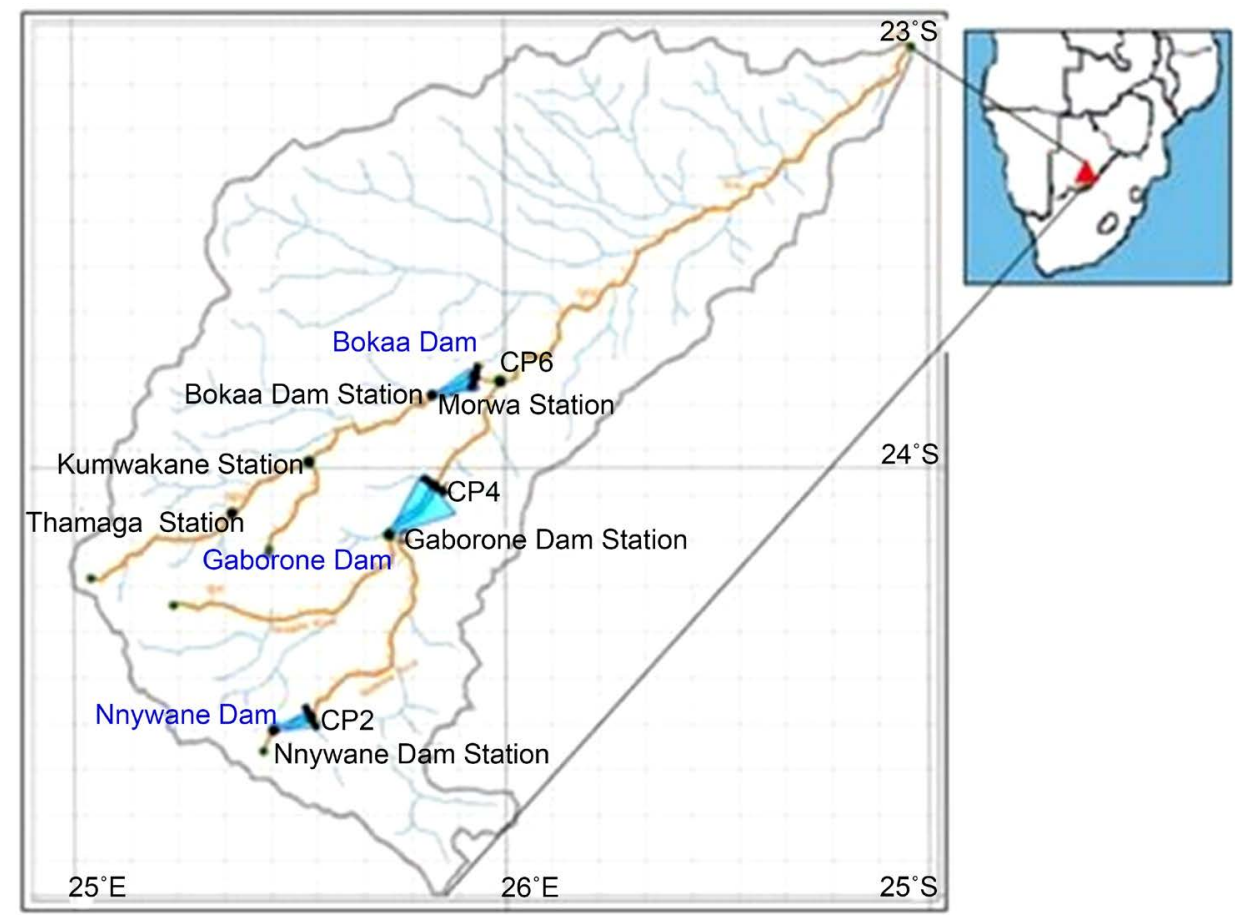

Figure 2. Study area showing dams and rivers in the Notwane catchment with watershed setup module of HEC-ResSim. 
that guide the release decision process.

The simulation model isolates the output analysis from the model development process. After the catchment and reservoir network together with alternatives are set up, computations are performed and results are viewed in the simulation module.

\subsection{RRA Model}

Water resource systems show a high level of complexity, hence measuring their performance is not straight forward. This complexity makes it a challenge to come up with indices or indicators to evaluate water resources performance. Generally, failures in the operation of a reservoir has many aspects including its extent, number and severity. Reliability, resilience and vulnerability indices (RRVs) were proposed [13]. Reliability (Table 2 ) is a metric that measures the proportion of time the reservoir can meet the stipulated demands while resilience (Table 2) indicates how quickly a system recovers after failure. A good system rapidly returns to a satisfactory state after failure. Vulnerability measures severity of failure if and when it occurs (Table 2). Usually, these indices are computed using daily, monthly or annual data from the reservoir system. In the recent past attempts have been to quantitavely represent sustainability of water resource managements by the composite indices made up of the combination of the three indices (RRV) [14] [15]. An integrated risk index namely the drought risk index (DRI), is given as a linear weighted function of reliability and resiliency and vulnerability [15] (Equation (1)).

$$
D R I=\beta_{1}(1-R e l)+\beta_{2}(1-R e s)+\beta_{3}(1-V u l)
$$

where Rel is reliability; Res is resilience and $V u l$ is vulnerability and $\beta_{1}+\beta_{2}+\beta_{3}=1$. $\beta_{1}, \beta_{2}$ and $\beta_{3}$ are weights and no guidelines are available to select the weights. The $D R I$ ranges from 0 - 1 with 1 indicating serious water shortage. The sustainability index (SUI) proposed by [14] is given as follows:

$$
S U I=[\operatorname{Rel} \times \operatorname{Res} \times(1-V u l)]^{\frac{1}{3}}
$$

$S U I$ values vary from $0-1$ and the value closer to 1 means the condition of water shortage is less serious. The SUI equation above (Equation (2)) means that if one of the performance criteria is zero, the sustainability will be zero also there is implicit

Table 2. Soil types and their seepage rates [22].

\begin{tabular}{cc}
\hline Natural soil type & Seepage water losses (in mm/day) \\
\hline Sand & $25.00-250$ \\
Sandy loam & $13.00-76$ \\
Loam & $8.00-20$ \\
Clayey loam & $2.50-15$ \\
Loamy clay & $0.25-5$ \\
Loamy clay & $0.25-5$ \\
Clay & $1.25-10$ \\
\hline
\end{tabular}


weighting because the index gives added weight to the criteria with the worst performance. In this study RRA model is applied and includes reliability, resilience and vulnerability. The results from the HEC-ResSim model were analyzed through the RRA model using Microsoft excel tool.

First a criterion, $C$, is defined for each dam, where an unsatisfactory condition occurs when a certain target demand is not met. The simulated time series of parameter of interest such as dams release/regulated outflow in our case is used as an indicator of system performance and is assigned $X_{\mathrm{t}}$ to be assessed in meeting the criterion Ct which is defined as the total demand that needs to be supplied in each time step (Equation (3)). Additionally, an index $Z_{\mathrm{t}}$ (Equation (3)) is expounded to quantify a satisfactory (S) or unsatisfactory $(U)$ state of the water system on the basis of the criterion, $\mathrm{Ct}$ [13]:

$$
\text { If } X_{t} \geq C \text { then } X_{t} \in S, Z_{t}=1 \text { else } X_{t} \in U, Z_{t}=0
$$

If the demand is met the system is in a satisfactory (S) state and $Z_{\mathrm{t}}$ is one, otherwise is in an unsatisfactory $(U)$ state and $Z_{\mathrm{t}}$ is zero. Another indicator $W_{\mathrm{t}}$, which indicates the transition from an unsatisfactory to satisfactory state;

$$
W_{t}=\left\{\begin{array}{l}
1, \text { if } X_{t} \in U \text { and } X_{t+1} \in S \\
0, \text { if otherwise }
\end{array}\right.
$$

If unsatisfactory periods of the dam's release, $X_{\mathrm{t}}$, are defined as $J_{1}, J_{2}, \cdots, J_{N}$ then reliability, resilience and vulnerability indices are defined as follows [13]:

$$
\begin{gathered}
C_{R}=\frac{\sum_{t=1}^{T} Z_{t}}{T} \\
C_{R S}=\frac{\sum_{t=1}^{T} W_{t}}{T-\sum_{t=1}^{T} Z_{t}} \\
C_{V}=\operatorname{mean}\left\{\sum_{t \in J_{i}} C-X_{t} i=1, \cdots, N\right\}
\end{gathered}
$$

The results from the evaluation of three indices are used as a weight of evidence to support the recommended decision and or conclusion. An efficient management and operational system should improve the reliability and resilience of the system while reducing vulnerability.

\subsection{Data Used}

Relevant and appropriate data are very important prior to simulation of any model in order to achieve the objectives of the research. Both historical and generated time series data are used for the study. The data applied in this research were gathered from the various departments (DWA, DMS and WUC), outputs of reports, personal communication with relevant stakeholders and journals. Data from the first National Water Master Plan of 1991 and its review in 2006 were widely used for the study. The information used included population, water demands, inflow, climatic, seepage, sedimenta- 
tion data and reservoir surface area-volume-elevation relationships, among others. Moreover, additional data for the study was collated through extensions for the simulation horizon using time series modeling based on calibration using historical data including:

- Daily potential evapotranspiration (ET) was calculated from disaggregated monthly ET values calculated from Penman-Monteith [16] formula.

- Hydrological Inflow Data in terms of streamflows gauging stations in the Notwane Basin at reservoir inflow stations of the three dams are mainly maintained by the department of Water Affairs (DWA) and are used in the study.

- Reservoir elevation-area-volume curves for the three dams were also available for the study and are input to the ResSim model.

Other set of generated time series data included the following:

a) Reservoir Inflows Time Series Modelling and Forecasting-Generation of future inflows into the reservoirs were conducted through performance evaluation of time series models applied including Autoregressive Integrated Moving Average (ARIMA) [17]. Under ARIMA we have subclasses of other models, such as the Autoregressive (AR), Moving Average (MA), Autoregressive Moving Average (ARMA) and Seasonal ARIMA (SARIMA) [18]. Artificial neural networks (ANNs) have been used recently [19] [20] [21] but were not considered in this study. In this study Autoregressive model of order one (AR1) was found to be the adequate model to reproduce the historical inflow time series data more accurately, hence was adopted.

b) Seepage Estimation-Reservoirs are prone to losses through evaporation and seepage-Seepage is the slow escape of a liquid through porous material from a dam. All earth dams have seepage due to water movement through the dam and its foundation, however, the rate of seepage must be controlled. For effective water resources management of reservoirs/dams/or small ponds, seepage calculation and estimation has become crucial as it affects the stability of any reservoir. Many factors affect amount of seepage water from the reservoir; wall or abutment of the reservoir, slope, soil type, bedrock type, dykes and volume and pressure of water. Although there are various factors affecting the rate of seepage, the material used in the construction and type of soil in the bed of the water reservoir are the main determinants to the rate of the seepage. Table 2 gives the rate of seepage losses in millimetres per day from various soil types;

To estimate quantity of water escaping as seepage, Table 2 and the following formula can be used:

$$
Q=q \times A
$$

where $Q=$ Seepage volume ( $\mathrm{m}^{3} /$ Day); $q=$ Seepage loss rate $(\mathrm{m} /$ day) and A = Surface Area of dam $\left(\mathrm{m}^{2}\right)$.

\subsection{Reservoir Operation Rule in HEC-ResSim}

Rules describe a minimum or maximum constraint on the reservoir releases based on a number of variables such as reservoir water level, date, inflow, outflow and many others 
depending on the information you have at your disposal. HEC-ResSim requires every reservoir to have a target elevation which is usually the top elevations of one of the operational zones. The reservoir's target elevation is called its Guide Curve and is presented as a function of time. For the Notwane dams, the guide curve was taken as the monthly maximum water elevations which make the top of the conservation zone. The criteria for determining the release from the reservoir is then based on where the current reservoir pool elevation is in relation to the guide curve. When the reservoir pool elevation is below the guide curve in the conservation zone/pool, the reservoir reduces releases of water as possible in order to refill the pool; if the reservoir pool elevation is above the guide curve in the flood control pool, then the reservoir releases more water as possible than is entering the pool to draw down the pool [12].

Various set of rules are added to each zone and the release decision process for HEC-ResSim is to determine the quantity of release for the guide curve operation. The priority of rules in HEC follows the order that the first listed rule in the storage zone has the highest priority than the one below it. An example of reservoir storage and rules on each storage zone is depicted in operation summary tables of the dams (Tables 3-5) where IF conditional statements have been used to indicate which rules apply in the reservoir release decision process.

HEC ResSim allows for hydropower reservoir operation rules, however this were not formulated or applied in this study because the reservoirs of the catchment do not and are not capable of hydropower generation.

\subsection{Development of Scenarios}

Scenarios were developed to evaluate the possible most likely events in the catchment. That is, what will transpire based on various conditions that may or may not change on the study area. This changes may be due to social, economic, climatic and environmental

Table 3. Operation summary of Bokaa dam.

\begin{tabular}{|c|c|c|}
\hline Name & Item & Description \\
\hline TOP OF DAM & $954.5 \mathrm{~m}$ & \\
\hline $\begin{array}{c}\text { FLOOD CONTROL } \\
\text { ZONE }\end{array}$ & $953.5 \mathrm{~m}$ & \\
\hline Induces surcharge & $\begin{array}{l}\text { Release water from Spillway using } \\
\text { defined release discharge }\end{array}$ & Forces flood flows over the spillway \\
\hline $\begin{array}{l}\text { CONSERVATION } \\
\text { ZONE }\end{array}$ & Varies between 954 and $953.5 \mathrm{~m}$ & $\begin{array}{l}\text { This is the range of the guide curve } \\
\text { elevation. Calculation is done } \\
\text { in Excel }\end{array}$ \\
\hline \multirow[t]{3}{*}{ Bokaa IF Functions } & $\begin{array}{c}\text { ELSE IF Bokaa Dam Pool }>953.5 \\
\text { Maximum release of } 1.5 \mathrm{cms}\end{array}$ & Spillways open \\
\hline & $\begin{array}{c}\text { ELSE IF Bokaa Dam Pool }>948 \text { and } \\
\qquad 954 \mathrm{~m} \\
\text { Normal release of } 0.13 \mathrm{cms}\end{array}$ & $\begin{array}{c}\text { Spillways closed } \\
\text { Controlled outlet open }\end{array}$ \\
\hline & IF Bokaa Dam pool $\leq 948 \mathrm{~m}$ & Spillways are closed \\
\hline INACTIVE ZONE & $\begin{array}{c}\text { Maximum Release of } 0 \mathrm{cms} \\
948 \mathrm{~m}\end{array}$ & $\begin{array}{c}\text { Controlled outlet closed } \\
\text { Dead storage, no releases below this } \\
\text { elevation }\end{array}$ \\
\hline
\end{tabular}


Table 4. Operation summary of Gaborone dam.

\begin{tabular}{|c|c|c|}
\hline Name & Item & Description \\
\hline TOP OF DAM & $998.5 \mathrm{~m}$ & \\
\hline $\begin{array}{l}\text { FLOOD CONTROL } \\
\text { ZONE }\end{array}$ & $998 \mathrm{~m}$ & \\
\hline Induces surcharge & $\begin{array}{c}\text { Release water from Spillway using } \\
\text { defined release discharge }\end{array}$ & Forces flood flows over the spillway \\
\hline $\begin{array}{l}\text { CONSERVATION } \\
\text { ZONE }\end{array}$ & Varies between 998 and $997.3 \mathrm{~m}$ & $\begin{array}{l}\text { This is the range of the guide curve } \\
\text { elevation. Calculation is done } \\
\text { in Excel }\end{array}$ \\
\hline \multirow[t]{4}{*}{ Gaborone IF Functions } & $\begin{array}{l}\text { ELSE IF Gaborone Dam Pool >998 m } \\
\text { Maximum release of } 3.6 \mathrm{cms}\end{array}$ & Spillways open \\
\hline & $\begin{array}{c}\text { ELSE IF Gaborone Dam Pool }>983 \\
\text { and }<998 \mathrm{~m} \\
\text { Normal release of } 0.63 \mathrm{cms}\end{array}$ & $\begin{array}{c}\text { Spillways closed } \\
\text { Controlled outlet open }\end{array}$ \\
\hline & IF Gaborone Dam pool $\leq 983 \mathrm{~m}$ & Spillways are closed \\
\hline & Maximum Release of $0 \mathrm{cms}$ & Controlled outlet closed \\
\hline INACTIVE & $983 \mathrm{~m}$ & $\begin{array}{c}\text { Dead storage, no releases below this } \\
\text { elevation }\end{array}$ \\
\hline
\end{tabular}

Table 5. Operation summary of Nnywane dam.

\begin{tabular}{|c|c|c|}
\hline Name & Item & Description \\
\hline TOP OF DAM & $1135.5 \mathrm{~m}$ & \\
\hline FLOOD CONTROL ZONE & $1135 \mathrm{~m}$ & \\
\hline Induces surcharge & $\begin{array}{c}\text { Release water from } \\
\text { Spillway using defined release } \\
\text { discharge }\end{array}$ & $\begin{array}{l}\text { Forces flood flows over the } \\
\text { spillway }\end{array}$ \\
\hline CONSERVATION ZONE & Varies between 1134.5 and $1135 \mathrm{~m}$ & $\begin{array}{l}\text { This is the range of the } \\
\text { guide curve elevation. } \\
\text { Calculation is done in Excel }\end{array}$ \\
\hline Nnywane IF Functions & $\begin{array}{c}\text { ELSE IF Nnywane Dam } \\
\text { Pool }>1135 \mathrm{~m} \\
\text { Maximum release of } 0.15 \mathrm{cms}\end{array}$ & Spillways open \\
\hline & $\begin{array}{c}\text { ELSE IF Nnywane Dam } \\
\text { Pool }>1129 \text { and }<1135 \mathrm{~m} \\
\text { Normal release of } 0.021 \mathrm{cms} \\
\text { IF Nnywane Dam pool } \leq 1129 \mathrm{~m} \\
\text { Maximum Release of } 0 \mathrm{cms}\end{array}$ & $\begin{array}{c}\text { Spillways closed } \\
\text { Controlled outlet open } \\
\text { Spillways are closed } \\
\text { Controlled outlet closed }\end{array}$ \\
\hline INACTIVE & $1129 \mathrm{~m}$ & $\begin{array}{l}\text { Dead storage, no releases } \\
\text { below this elevation }\end{array}$ \\
\hline
\end{tabular}

factors associated with dams. Future inflow generated as described in subsequent sections was used in this section. Eight scenarios were established each to be run on the three reservoirs for a period of 40 years from January 2011 to November 2050 and their results compared and scrutinized in relation to the historical baseline simulation.

i. Baseline Scenario: A time period of eighteen years was selected to create a baseline with which to compare future water availability and performance. The baseline scenario is the historical simulation from year 1993 to 2010. In this scenario the model was run using the known inflows after which the obtained water outputs were analysed using the RRA model. It is assumed that water demand patterns and water 
system conditions, do not change over this period. That is to say the demand was assumed to be constant throughout the simulation period.

ii. Population and urbanization Scenario: In this scenario, the effect of a growing population and urbanization on water resources is analysed. In order to establish the water demand up to the year 2050, population data from Central Statistics Office (CSO) and water demand information from DWA were used. The mean annual population growth rates were computed using population data from the Botswana population census of 2001 and 2011 (Table 6). The mean monthly abstraction is multiplied by the annual population growth rate. The annual population growth rate was determined as the average of the annual growth rates for the towns and villages in the Notwane catchment that are supplied by the dams. This is illustrated in Table 6.

iii. Climate change Scenario: Plenty of scientific evidence has indicated that the climate may change during the next years, decades and centuries, both globally and locally, due to increased concentrations of greenhouse gases in the atmosphere. The increase in these gases is mainly due to human activities, such as the use of fossil fuels. The overwhelming majority of general circulation models predict a rainfall decrease in Botswana and a rise in temperatures. Temperatures are projected to rise by $1^{\circ} \mathrm{C}$ to $3^{\circ} \mathrm{C}$ during the next 50 years as a result of global warming caused by the release of greenhouse gases. Hulme, 1996 predicted a $20 \%$ decline in rainfall over the SADC region and a $13 \%-20 \%$ decline in inflows. The Notwane river basin revealed a decline in rainfall , a $0.132^{\circ} \mathrm{C}$ per annum increase in temp and an increase in evaporation each contributing to 20,11 and $16 \%$ reduction in annual yields [20]. Therefore, in this scenario inflows to the dams were decreased by $20 \%$ while evaporation was increased in accordance with the $3^{\circ} \mathrm{C}$ surge of temperatures. The demand during the simulation period of the climate change scenario was kept constant.

Table 6. Determination of the mean annual growth rate [1].

\begin{tabular}{cccc}
\hline GREATER GABORONE & 2001 Population & 2011 Population & \% Annual Growth Rate 2001-2011 \\
\hline Gaborone & 186,007 & 227,333 & 2.03 \\
Lobatse & 29,689 & 29,032 & -0.22 \\
Tlokweng & 21,133 & 35,982 & 5.47 \\
Metsimotlhabe & 4056 & 8081 & 7.14 \\
Oodi & 3440 & 5464 & 4.74 \\
Kopong & 5571 & 9320 & 5.28 \\
Ramotswa & 2423 & 27,760 & 2.99 \\
Mogoditshane & 2461 & 57,637 & 5.79 \\
Mmopane & 3812 & 14,655 & 15.4 \\
Mochudi & 2696 & 44,339 & 1.84 \\
Gabane & 20,680 & 14,842 & 3.62 \\
& Mean Annual Growth Rate & & 4.45 \\
\hline
\end{tabular}


iv. Abstraction Patterns Scenario: The Botswana National Water Act of 1968 (Water Act 1968 Cap 34.010 and the Draft water bill of 2004 [23] have provided an enabling environment for water conservation and demand management. Limpopo Watercourse Commission (LIMCOM) has identified water conservation and demand management strategies as important tools to assist in the reconciliation of water demands and water resources in the wider Limpopo River basin catchment of which the Notwane catchment is a part of. With this in mind the Abstraction Patterns scenario was established to examine, the effect of water saving techniques on the dams. The water saving techniques and strategies include water-rationing, rainwater harvesting, recycling, and other water conservation techniques. The water demand up to the year 2050 is kept constant in this scenario as in the baseline. It is assumed that these strategies and techniques reduce the water demand by $20 \%$. Therefore, in HEC-ResSim the mean abstractions are decreased by twenty percent for the simulation period.

v. Seasonal Operation: The seasonal Operation scenario focuses on operating the reservoirs according to seasons. Abstraction data from WUC for the Gaborone dam for 2000 to 2010 and seasonal average/ monthly average abstraction of Gaborone, Bokaa and Nnywane dams were used for the study In this scenario, HEC-ResSim is directed to ensure that during the wet season months a higher range of abstractions is released while during the dry season months a low range of abstractions as possible are released while also meeting the demand.

vi. Sedimentation Scenario: Impounding of natural watercourses alters flow regime from flowing water to a body of stagnant water, which favours sediment accumulation. Sedimentation in reservoirs leads to; increased flood risk on influent streams, loss of storage capacity with associated loss of reservoir yield, severe blockage of draw-off works resulting in reservoir drawdown to excavate sediment or abandonment of clogged bottom outlets and increased abrasion of steel hydraulic works and equipment by sediments. As a consequence of these, a sedimentation scenario was developed to examine the future response of dams to sedimentation. Demand or water abstractions were retained constant. HEC-ResSim unfortunately does not contain provision for the inclusion of sedimentation directly. This has meant that the impact of reservoir sedimentation can only be assessed by examining system performance with varying storage capacity. The remaining storage of dams that was used in the simulation is presented in Table 7.

Plots of the residual storage capacities at specific years for the dams was done and their respective extrapolation equations are depicted in Figure 3.

From the three plots above and their respective equations, residual storage from the year 2015 to 2050 were extrapolated.

The percentage decrease in storage tabulated in Table 8 is used to reduce the storage capacity in the storage-area data of the dam for each of the particular five-year range. This was repeated for Gaborone and Nnywane dams as well. This is entered in the Reservoir Network module of HEC-ResSim's sedimentation scenario where physical data is an input. 
Table 7. Estimated residual storage capacity in MCM [23].

\begin{tabular}{ccccccccc}
\hline Name of dam & 2000 & 2005 & 2010 & 2015 & 2020 & 2025 & 2030 & 2035 \\
\hline Gaborone & 140.5 & 139.4 & 138.3 & 137.2 & 136.1 & 135.09 & 133.9 & 132.8 \\
Shashe & 75.05 & 72 & 68.95 & 65.9 & 62.85 & 59.8 & 56.75 & 53.7 \\
Letsibogo & 104.4 & 102.6 & 100.9 & 99.15 & 97.4 & 95.65 & 93.9 & 92.15 \\
Dikgatlhong & 397.6 & 394.1 & 390.6 & 387.1 & 383.6 & 380.1 & & \\
Bokaa & 18.2 & 17.9 & 17.6 & 17.3 & 17 & 16.7 & 16.4 & 16.1 \\
Nnywane & 2.28 & 2.24 & 2.20 & 2.16 & 2.12 & 2.09 & 2.05 & 2.016 \\
\hline
\end{tabular}

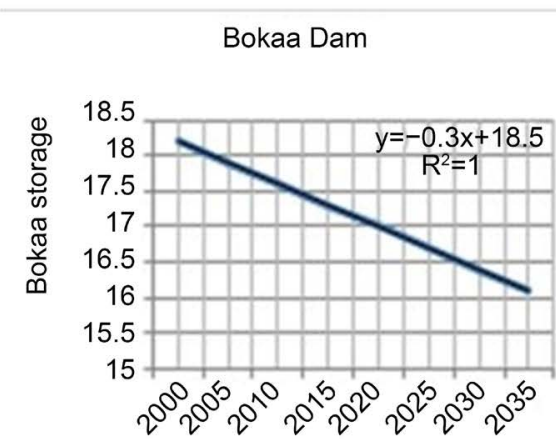

(a)
Gaborone Dam

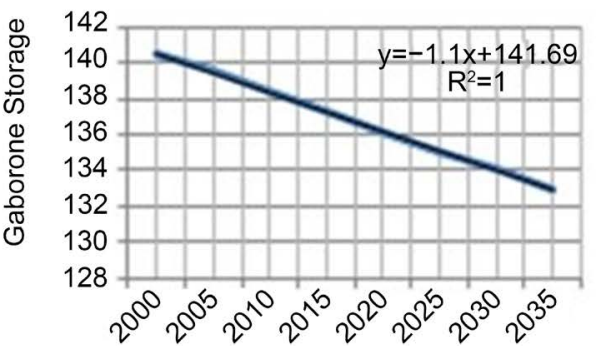

(b)

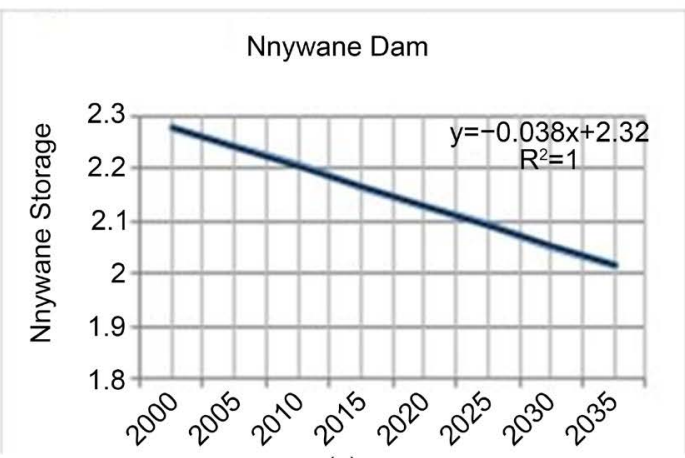

(c)

Figure 3. Plots of residual storage and extrapolated equations for the three dams.

Table 8. Extrapolated remaining storage of Bokaa dam.

\begin{tabular}{cccccccccccc}
\hline Year & 2000 & 2005 & 2010 & 2015 & 2020 & 2025 & 2030 & 2035 & 2040 & 2045 & 2050 \\
\hline $\begin{array}{c}\text { Storage }(\mathrm{MCM}) \\
\begin{array}{c}\text { \% decrease } \\
\text { 18.2 }\end{array}\end{array}$ & 17.9 & 17.6 & 17.3 & 17 & 16.7 & 16.4 & 16.1 & 15.8 & 15.5 & 15.2 \\
& & & & 6.59 & 8.24 & 9.89 & 11.5 & 13.1 & 14.8 & 16.4 \\
\hline
\end{tabular}

The various operational scenarios included in the analysis are the following.

a) Normal Operation Scenario-It is the business-as-usual mode of operation. Business as usual is a scenario for future patterns of activity which assumes that there will be no significant change in the people's attitudes and priorities, or no major changes in reservoir operation policies, so that normal circumstances can be expected to continue unchanged. The Normal Operation means operating the dams as 
they were in the historical period. This includes maintaining the mean water demands and evaporation, but the only difference is that the simulation is run using the future generated inflows.

b) Pessimistic Scenario-It is concerned at many of the things that could go wrong and tries to help decision makers plan responses to deal with these problems should they happen. These could be to loss of inflow due to diversions in the catchment, high infiltration due to human activities and change in land use. With that in mind, the Pessimistic scenario was developed to look at the response of dams if the inflows to the dams are lessened by twenty percent. The demand was kept constant and all the future inflows deducted by twenty percent.

c) Optimistic Scenario-This scenario introduces question as to what things or events would or could happen to result in a better than anticipated outcome and how can the reservoir operators or managers make those things happen? The Optimistic scenario indicates an increase in water availability and a constant water demand. In this scenario, the rivers inflow in the Normal Operation scenario is increased by $20 \%$. Human activities and change in land use and land management practices have great effect on the runoff yield and consequently increase in inflows. E.g., an area with forest cover or thick layer of mulch of leaves and grasses contribute less runoff because water is absorbed more into soil than areas that are paved.

\section{Results and Discussions}

\subsection{Model Calibration}

The model was calibrated separately for each dam using simulated and observed water levels at each dam. The comparison of the hydrographs representing simulated and observed water levels from HEC-ResSim for Gaborone dam is exhibited in Figure 4.

The values for $\mathrm{R}^{2}$ and for NS coefficient for the fit of the daily water levels (elevation) for the calibration period are 0.81 and $0.60,0.62$ and 0.27 and 0.54 and 0.39 respectively for the Bokaa, Gaborone and Nnywane dams in that order. Based on the performance statistical parameters of the model for prediction, the model calibration is satisfactorily accepted.

\subsection{Model Verification}

In verification, the model should be tested with independent data without any adjustment of the parameter values determined in calibration in order to evaluate the efficiency of the model for future predictions of water levels in the dams of the watershed. Comparison of hydrographs representing simulated and observed water levels for the verification period from HEC-ResSim is shown in Figure 5.

Therefore, values for $\mathrm{R}^{2}$ and for NS coefficient for the fit of the daily-simulated water levels (elevation) to the observed pool elevation for model verification are 0.53 and 0.01 respectively for Bokaa dam, 0.91 and 0.52 respectively for Gaborone dam and 0.76 and 0.75 respectively for Nnywane dam. Even though the NS and $\mathrm{R}^{2}$ values are reasonable, there is generally underestimation and overestimation in model performance accuracy 


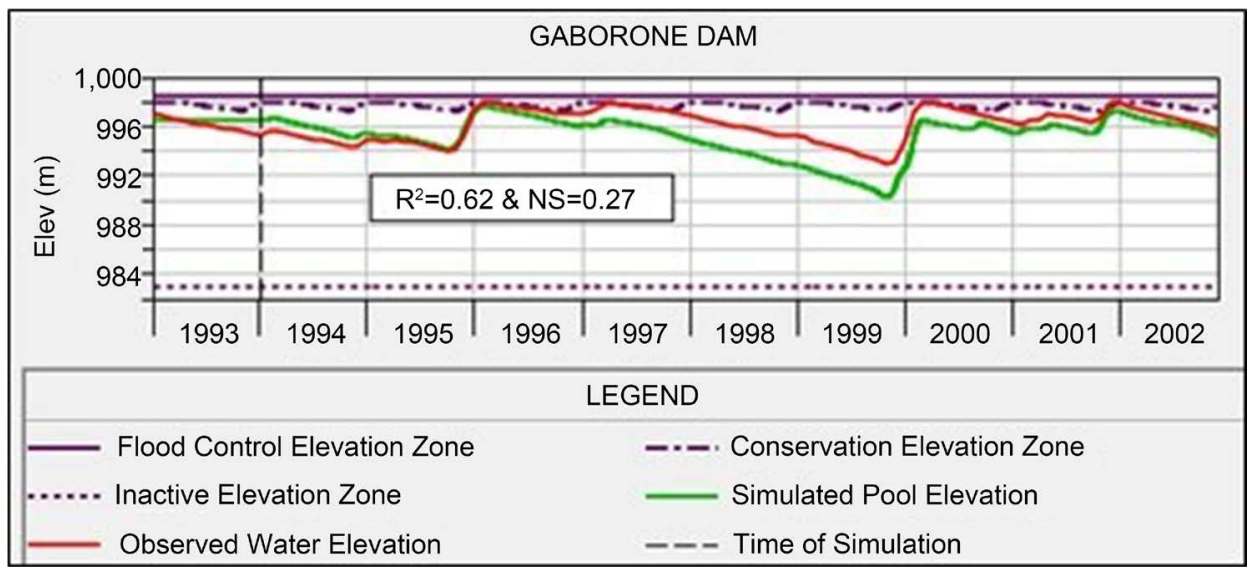

Figure 4. Simulated and observed hydrographs comparison for Gaborone Dam in Calibration Mode.

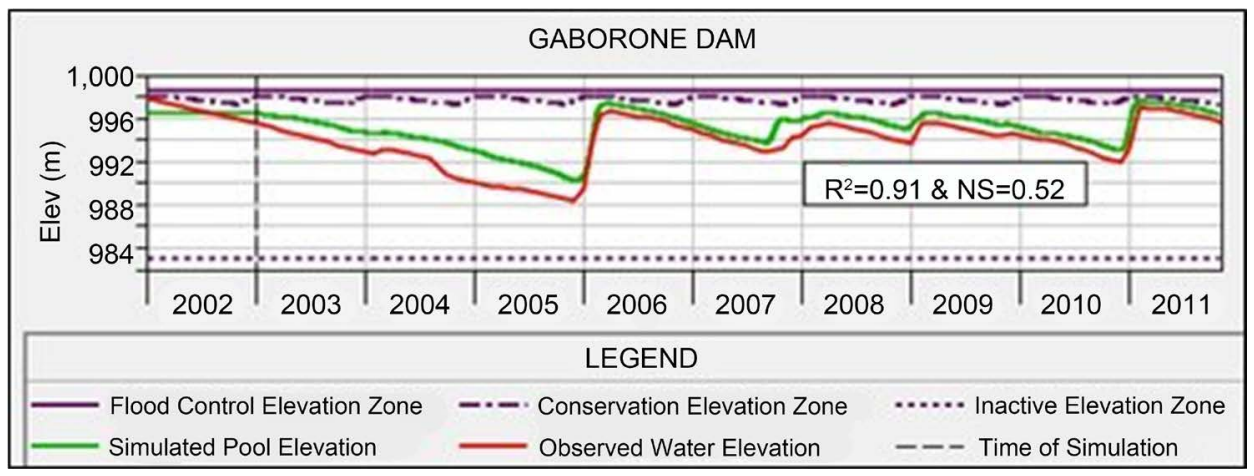

Figure 5. Mode Simulated and observed hydrographs comparison for Gaborone Dam in verification mode.

for both calibration and verification. This anomaly could be attributed to the following factors: use of mean evaporation and mean abstraction rates which does not account for the seasonal patterns of demand. To address or improve these anomalies more field observed or measured data is required through enhanced monitoring by the DWA and WUC. Despite this data shortfall the set of optimised parameters can be described as the representative parameters for the dams of Notwane watershed.

\subsection{HEC ResSim and RRA Model Results}

The results of the simulation in HEC-ResSim are evaluated utilizing the RRA model in Figures 6-8.

The reliability results for Gaborone dam scenarios (Figure 6), shows that the reliability for water supply for all scenarios is lower than the baseline scenario indicating a possible bleak future for the dam and the water supply situation in the Greater Gaborone area. Bokaa dam scenarios are more reliable than the other dams followed by Nnywane and lastly comes Gaborone dam (Table 9 and Figure 6). The scenarios of population and urbanization, climate change and Pessimistic most of the time reduce the reliability and resilience of water supply for the dams. 


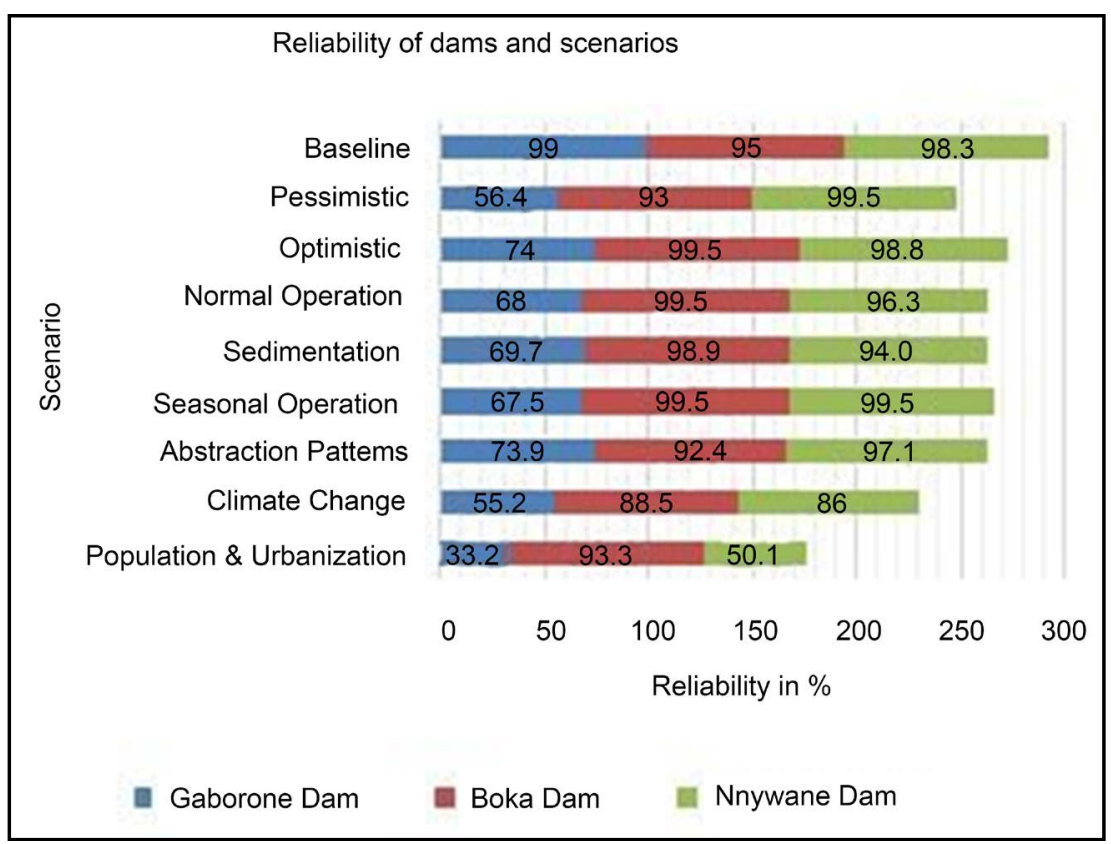

Figure 6. Reliability of dams and their scenarios.

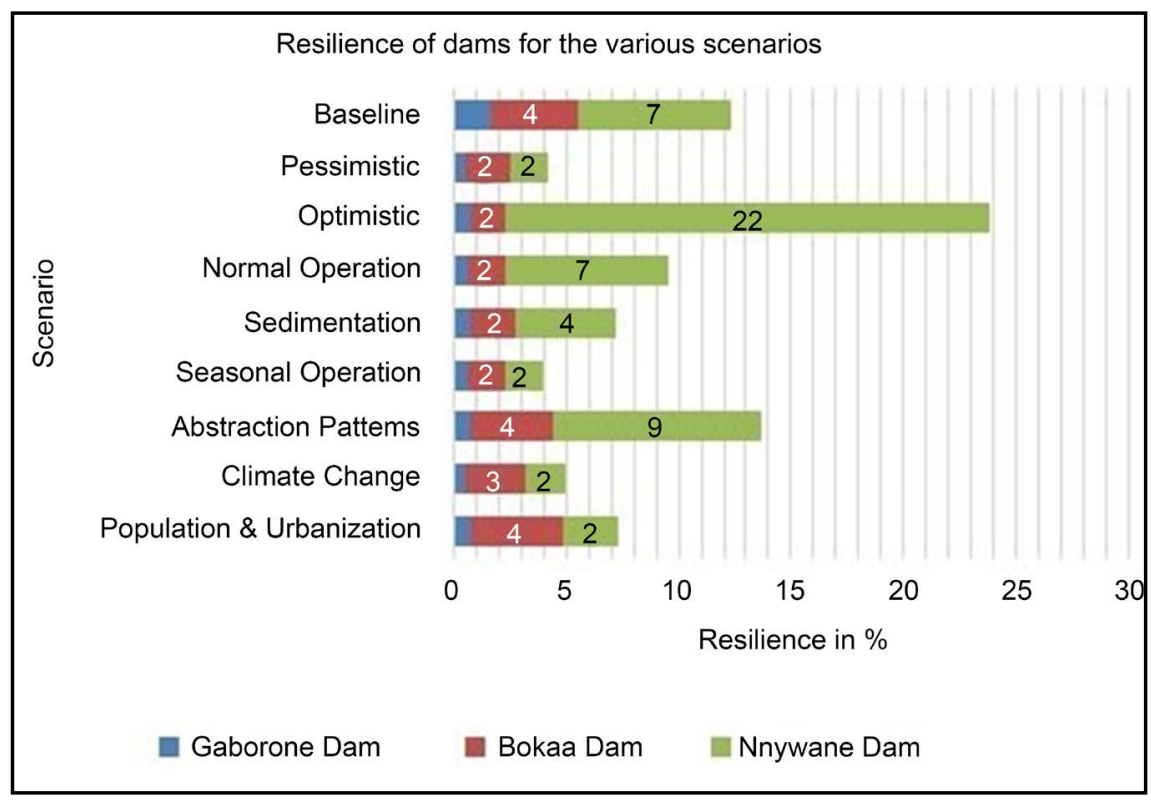

Figure 7. Resilience of dams and their scenarios.

The average resilience of the dams presented in Table 9 indicates that Nnywane dam scenarios are the most resilient as Nnywane, Bokaa and Gaborone have resilience averages of $6.3 \%, 2.7 \%$ and $0.74 \%$ respectively. It was also noted from Figure 7, that the Optimistic, Normal Operation and Abstraction Patterns scenarios are the most resilient.

The vulnerability of the dams indicates that Bokaa dam is the least vulnerable succeeded by Nnywane and lastly Gaborone dam. According to Figure 8 and Table 9, the "average as percentage of demand row" shows percentages of $61.2 \%, 50 \%$ and $41.4 \%$ for 


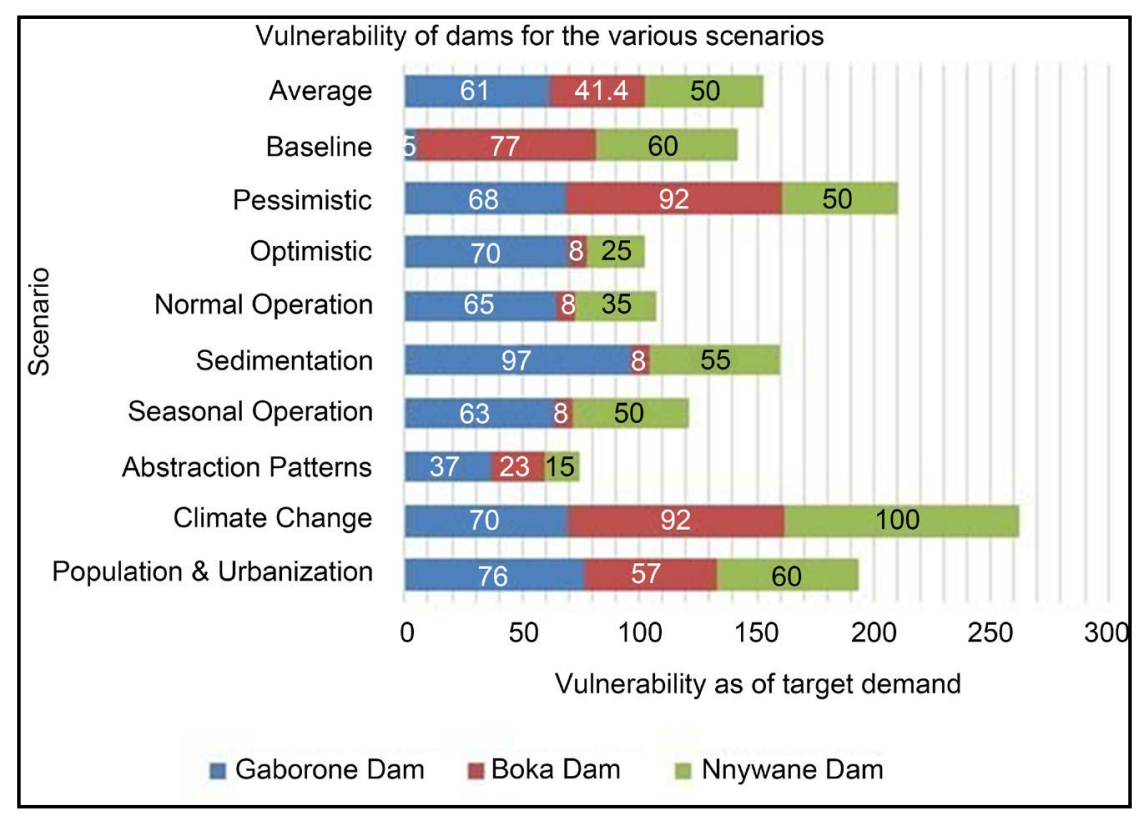

Figure 8. Vulnerability of dams and their scenarios.

Table 9. Mean of Reliabilities, Resilience and Vulnerability of dams and their scenarios.

\begin{tabular}{cccc}
\hline Index & Gaborone Dam & Bokaa Dam & Nnywane Dam \\
\hline Reliability \% & 66.3 & 95.0 & 91.1 \\
Resilience \% & 0.74 & 2.73 & 6.32 \\
$\begin{array}{c}\text { Vulnerability (Average as \% of } \\
\text { historical or target mean demand }\end{array}$ & 61.2 & 41.4 & 50.0 \\
\hline
\end{tabular}

Gaborone, Nnywane and Bokaa dams. This least vulnerability of Bokaa improves the performance of Bokaa dam as compared to the other two dams because in vulnerability performance index, the lower the value the better the vulnerability and performance. From the results it is also evident that the scenarios of Population growth and Urbanization, Climate Change and Pessimistic that have low reliability and resilience are also highly vulnerable. This insinuates that the pressure they will exert on the water resources due to population growth and urbanization and change in climate will be too much for the reservoir's reliability for water supply. In consequence, the larger Gaborone dam water supply capability will be hardly hit as it performs poorly in all the three performance indexes.

\section{Conclusions and Recommendation}

The following conclusions are drawn from the study:

- The reliability and resilience for water supply for all scenarios of the Gaborone dam is lower than the historical period indicating a possible dreary future for the dam.

- The scenario of Climate Change reduces reliability of water supply for the dams by $7 \%, 13 \%$ and $44 \%$ as compared to the historical period for Bokaa, Nnywane and Gaborone dams. 
- The scenario of Population and Urbanization greatly lessens the reliability of the Gaborone, Bokaa and Nnywane reservoirs by $66 \%, 2 \%$ and $49 \%$ respectively, signifying the detriment that an ever-increasing population and rapid urbanization place on the dam during the simulation period.

- Sedimentation on the dams affect the storage by reducing the storage, as the percentage of time the demand met is decreased. This is verified by a decline in reliability of water supply by $30 \%, 1 \%$ and $4 \%$ for Gaborone, Bokaa and Nnywane dams.

- Bokaa dam scenarios on average are more reliable than the other dams followed by Nnywane and Gaborone dam respectively whereas the scenarios of Population and Urbanization, Climate Change and Pessimistic most of the time diminish the reliability of water supply of the dams.

- The resilience of all scenarios for all the dams is very low expressing the low speed of recovery of the dams from failure states to satisfactory states. The Optimistic, Normal Operation and Abstraction Patterns scenarios are the most resilient.

- Bokaa dam is the least vulnerable followed by Nnywane and Gaborone dams respectively.

The following recommendations were made:

- HEC-ResSim does not have the capability to perform simulations on a monthly time interval. This limits ability to make period-of-record analysis and evaluation for water supply operations, therefore HEC must avail the ability to perform simulations on monthly time period.

- The stakeholders involved in water resources management must do more to encourage and promote water saving techniques/water conservation to reduce the burden on demand. Incentives should be used to encourage efficient water use, reuse and recycling.

- Increase in gauging stations and better management of these stations, frequent monitoring and better data keeping, and recording. These will improve on data gaps, erroneous data readings and quality found in data obtained from WUC and DWA.

- Trapping of sediment by dams is not inevitable, at least not by all dams. However, sediment management approaches are not sufficiently used in many reservoirs in the catchment. Mitigation measures such as reduction of sediment production, soil erosion control and sediment traps before the dams to reduce sediment yield in the watershed are invaluable. Also minimizing sediment deposition on the reservoirs by measures such as mechanical excavation and drawdown routing (sluicing) should be looked at especially when the dams are empty like recently when Gaborone dam was empty for the period 29/01/2015 to 29/03/2016, a total of 14 months [7].

The Government of Botswana wishes to strengthen the local capacity in terms of improving water use efficiency [24] [25]. While reducing water consumption can be successful in the catchment, the loss of water from reservoir evaporation is an issue already affecting the dams especially with the possibility of decreasing precipitation occurring as a result of climate change. Hence, we suggest the water managers to look at proposals such as moving reservoir water underground into new storage areas or aquifers and the 
selection of future reservoir sites should be selected in such a way that the area to storage ratio is minimum. Also recently the city of Los Angeles rolled out thousands of small, shade black plastic balls into the 175-acre Los Angeles Reservoir in Sylmar, California to reduce water evaporation from the reservoir. The black plastic balls are also used as floating covers to protect water quality by preventing sunlight-triggered chemical reactions that give birth to carcinogens, deterring birds and other wildlife, and protecting water from rain and wind-blown dust in reservoirs [26]. Made of black polyethylene, shade balls are filled with water so they do not blow away and a coating resists ultraviolet light and degradation. The manufacturers (Xavier C, Artisan Screen Process, and Orange Products) say the balls should last about 25 years. The 96 million balls that were deployed into the reservoir were a cost-effective investment that is expected to save the city at least $\$ 250$ million in comparison to other water-saving alternatives. They are currently in place at Upper Stone, Elysian and Ivanhoe reservoirs, and come with the added benefit of reducing evaporation off the reservoir surfaces by $85 \%$ to $90 \%$ equating to saving nearly 300 million gallons a year according to a press release from Los Angeles [26].

\section{Acknowledgements}

The authors wish to appreciate the support of the University of Botswana and Department of Metrological Services and Department of Water Affairs of the Botswana Government for encouraging this research directly or indirectly by providing the necessary information and support.

\section{References}

[1] CSO (2009) Botswana Water Statistics, Population Census of Botswana. Central Statistics Office, Gaborone.

[2] Guo, S., Chen, J., Li, Y., Liu, P. and Li, T. (2011) Joint Operation of the Multi-Reservoir System of the Three Gorges and the Qingjiang Cascade Reservoirs. Energies, 4, 1036-1050. http://dx.doi.org/10.3390/en4071036

[3] Loucks, D.P., Stedinger, J.R. and Haith, D.A. (1981) Water Resource Systems Planning and Analysis. Prentice Hall, Englewood Cliffs.

[4] Simonovic, S.P. (1992) Reservoir Systems Analysis: Closing Gap between Theory and Practice. Journal of Water Resources Planning and Management, 118, 262-280. http://dx.doi.org/10.1061/(ASCE)0733-9496(1992)118:3(262)

[5] Wurbs, R.A. (2012) Generalized Models of River System Development and Management. Texas Water Journal, 3, 26-24.

[6] Labadie, J. (1997) Reservoir System Optimization Models. Water Resources Update, University Council on Water Resources No. 108, Summer, 83-110.

[7] WUC (2015) Dam Levels and Water Supply Situation. http://www.wuc.bw/wuc-content.php?cid=109

[8] HEC (1981) HEC-3: Reservoir System Analysis for Conservation User's Manual. US Army Corps of Engineers, Institute for Water Resources, Hydrologic Engineering Center, Davis.

[9] HEC (1989) HEC-5: Simulation of Flood Control and Conservation Systems. US Army Corps of Engineers, Institute for Water Resources, Hydrologic Engineering Center, Davis. 
[10] HEC (2003) HEC-ResSim, Reservoir System Simulation User's Manual, Version 2.0. US Army Corps of Engineers, Institute for Water Resources, Hydrologic Engineering Center, Davis.

[11] HEC (2007) HEC-ResSim, Reservoir System Simulation User's Manual, Version 3.0. US Army Corps of Engineers, Institute for Water Resources, Hydrologic Engineering Center, Davis.

[12] HEC (2013) HEC-ResSim Reservoir System Simulation. User's Manual. Version 3.1. US Army Corps of Engineers, Hydrologic Engineering Center.

[13] Hashimoto, T., Loucks, D.P. and Stedinger, J. (1982) Reliability, Resilience and Vulnerability for Water Resources System Performance Evaluation. Water Resources Research, 18, 1420. http://dx.doi.org/10.1029/WR018i001p00014

[14] Loucks, D.P. (1997) Quantifying Trends in System Sustainability. Hydrological Sciences Journal, 42, 513-530. http://dx.doi.org/10.1080/02626669709492051

[15] Zongxue, X., Jinno, K., Kawanura, A., Takesaki, S. and Ito, K. (1998) Performance Risk Analysis for Fukuoka Water Supply System. Water Resources Management, 12, 13-30. http://dx.doi.org/10.1023/A:1007951806144

[16] Allen, R.G., Pereira, L.S., Raes, D. and Smith, M. (1998) FAO Irrigation and Drainage Paper NO. (56 1998) Crop Evapotranspiration. Guidelines for Computing Crop Water Requirements, United Nations, Rome.

[17] Box, G. and Jenkins, G. (1970) Time Series Analysis: Forecasting and Control. Holden-Day, San Francisco.

[18] Hipel, K.W. and McLeod, A.I. (1994) Time Series Modelling of Water Resources and Environmental Systems. Elsevier, Amsterdam.

[19] Zhang, G.P. (2003) Time Series Forecasting Using a Hybrid ARIMA and Neural Network Model. Neurocomputing, 50, 159-175. http://dx.doi.org/10.1016/S0925-2312(01)00702-0

[20] Parida, B.P., Moalafhi, D.B. and Kenabatho, P.K. (2006) Forecasting Runoff Coefficients Using ANN for Water Resources Management: The Case of Notwane Catchment in Eastern Botswana. Physics and Chemistry of the Earth, 31, 928-934. http://dx.doi.org/10.1016/j.pce.2006.08.017

[21] Parida, B.P., Moalafhi, D.B. and Kenabatho, P.K. (2006) Forecasting Runoff Coefficients Using ANN for Water Resources Management: The Case of Notwane Catchment in Eastern Botswana. Physics and Chemistry of the Earth, 31, 928-934. http://dx.doi.org/10.1016/j.pce.2006.08.017

[22] Moalafhi, D.B., Parida, B.P. and Kenabatho, P.K. (2014) A Hybrid Stochastic-ANN Approach for Flow Partitioning in the Okavango Delta of Botswana. Global NEST Journal, 16, 68-79.

[23] FAO (2014) How to Calculate Water Losses Caused by Seepage. ftp://ftp.fao.org/fi/CDrom/FAO_Training/FAO_Training/General/x6705e/x6705e02.htm

[24] DWA (Department of Water Affairs) (2004) A Policy for Achieving a Water-Wise and Water-Efficient Botswana. Draft Water Conservation Policy, July 2004. Gaborone.

[25] National Water Master Plan Review, SMEC and EHES (2006) Water Development Modelling, Vol. 11, Department of Water Affairs, Ministry of Mineral, Energy and Water Resources, Gaborone.

[26] National Geographic (2015) Why Did LA Drop 96 Million “Shade Balls" into Its Water? http://news.nationalgeographic.com/2015/08/150812-shade-balls-los-angeles-California-dr ought-water-environment/ 
Submit or recommend next manuscript to SCIRP and we will provide best service for you:

Accepting pre-submission inquiries through Email, Facebook, LinkedIn, Twitter, etc. A wide selection of journals (inclusive of 9 subjects, more than 200 journals)

Providing 24-hour high-quality service

User-friendly online submission system

Fair and swift peer-review system

Efficient typesetting and proofreading procedure

Display of the result of downloads and visits, as well as the number of cited articles

Maximum dissemination of your research work

Submit your manuscript at: http://papersubmission.scirp.org/

Or contact jwarp@scirp.org 